\title{
How to Use Lean Six Sigma to Improve Service Processes in Higher Education: A Case Study
}

$\mathrm{Na} \mathrm{Li}$

Email:111837@purdue.edu

Susan Ely

Email: sley@purdue.edu

Chad Laux

Email: claux@purdue.edu

Purdue Polytechnic, Purdue University

\begin{abstract}
Purpose: The purpose of this paper is to explore how to use Six Sigma to improve the service process in higher education.

Design/Methodologies/Approach: This article summarized the previous literature to illustrate the differences between service and manufacturing process from the lens of Six Sigma, and used a practical case study from higher education to explain how to implement the framework of DMAIC in service process and the challenges occurred during implementation.
\end{abstract}

Findings: We described a case study where Lean Six Sigma (LSS) principles were adapted at the Purdue Sponsored Program Services (SPS) Pre-Award office, which is dedicated to supporting the creation of quality proposals and contracts for staff at Purdue. We described how a LSS team worked with the team to apply DMAIC in their service process, defining potential benefits such as reduced service lead-time, lower work-in-process inventory and improvement on imbalanced workflow. This case study demonstrates the numerous challenges in working with the intangible factors that hard to recognize, quantify, and analyze.

Practical Implications: It is important for practitioners to be aware of the implementation of Six Sigma in service industry, because service operations comprise $80 \%$ of the GDP in United States. The nature of service project decides the complexity to identify what to improve, and methodology. The article provides suggestions on how LSS tools and principles can be applied while running projects in a service environment.

Originality: Six Sigma has been widely used in manufacturing, but there has been limited academic research about the implementation in service industry, particular to higher education. This article contributes through demonstration the value of the DMAIC methodology in service process and identifies challenges for higher education.

Keywords: Six Sigma, DMAIC, Service, Higher Education

Paper Type: Research Paper 


\section{Introduction}

In this paper, the authors introduced a Six Sigma project in a service department in an Institution of Higher Education and explored the challenges met during the application. The objective of this paper is to use a practical case study to demonstrate the power to utilize Six Sigma to improve service process in Higher Education. The authors utilized DMAIC methodology to help this service department to improve the current customer service level and provided detailed descriptions about the whole problem solving processes. The specialty of this service process is that customers' various expectations, communication method and even their personality play a critical role in the success of performance. High human behavior component dramatically increases the unpredictability of the whole service delivery process and then highly increases the complexity to identify the root cause for Six Sigma team. The key research questions are how to utilize effectively Six Sigma to improve service process in higher Education? What are the major obstacles and lessons learnt from this practical case study?

\subsection{Lean Six Sigma in Service Organizations}

Six Sigma is a rigorous, focused and highly effective implementation of proven quality principles and techniques (Pyzdek \& Keller, 2014). Six Sigma aims to control the errors in business performance within 3.4 per million opportunities. With high profile adoptions by companies such as General Electric (GE) in the mid-1990s, Six Sigma spread like wild fire toward the end of the twentieth century (Goh,2002). Lean Six Sigma for service is a business environment methodology that maximizes shareholder value by achieving the fastest rate of improvement in customer satisfaction, cost, quality, process speed, and invested capital (George, 2003).

Kumar et al. (2008) pointed out that one of the most common myths about Six Sigma is that it is good only for manufacturing processes because the application of Six Sigma was originally limited to manufacturing and the application of Six Sigma has difficulties and challenges, especially in service. It is true that current service sector has been considerably slower in embracing Six Sigma than the manufacturing sector (Furterer \& Elshennawy, 2005), however more and more organizations realize the benefits from Six Sigma in cost reduction and customer satisfaction. Based on research, the percentage of academic articles for focused on Lean Six Sigma in services doubled from only $20 \%$ to $40 \%$ during 5 years (Tjahjono et al., 2013). Besides, Service operations, which are comprised more than $80 \%$ of GDP in the United States, are still growing rapidly around the world (George \& George, 2003). Even in manufacturing industry, there is only $20 \%$ of product prices which are driven by direct manufacturing labor and $80 \%$ origins from indirect cost, which is associated with support and design functions (George, 2003), such as human resources, accounting and customer relations. There are many literature papers illustrated the application of Six Sigma in service, however the examples and applications are mainly focused on highly repetitive service process (Nakhai \& Neves, 2009), which has the similar nature of manufacturing. The authors believe that there exists a research gap for the practical application of Six Sigma in service process which contained high human behavior component and various customer expectations.

George (2003) illustrated the three key reasons why service process need to apply Lean Six Sigma: 
(1) Service processes are usually slow process, which are expensive process

(2) Service processes are slow because there is far too much "Work-in-Process" (WIP). It is resulted from the unnecessary complexity in the service/product offering.

(3) In any slow process, $80 \%$ of delay is caused by less than $20 \%$ of the activities.

\section{Case study}

\subsection{Business Environment Prior to Six Sigma Deployment}

The Purdue Sponsored Program Services (SPS) Pre-Award office coordinates the activities related to submitting grant proposals for every academic college and Purdue Discovery Park. While previously the SPS Pre-Award offices were assigned per college, the newly restructured department uses a centralized office management and centralized staff. In the SPS office, success is often defined by factors Critical to Quality and Critical to Schedule. An examination of the current state of the SPS Pre-Award office revealed that the current workload varies between 250 and 500 proposals per month, with each case requiring between 4 and $80+$ hours of work. Each proposal is assigned a priority factor, which is linked to the potential amount of the award, but not always determined solely by award potential. Variations in processing times are impacted by the complexity of the grant, the experience of the individual processing the grant and communication within the department and with other related departments at Purdue. Variation in monthly workload impacts worker morale and effectiveness, efficiency in processing proposals and the ability to complete all proposals in the timeline required by the granting agency. The entire SPS staff is organized into cross-functional teams with responsibility for: Proposals, Award Management, Contract and License Negotiation, Data Access and Support Services, Research Administration, Regulatory Compliance and Agricultural and International Programs. Currently, the Pre-Award SPS has one director, four managers and twenty specialists. Among the total twenty specialists, eight to ten are level-one specialists and are all new employees; six are level-two specialists and only four of them are senior specialists (See Figure 1). 


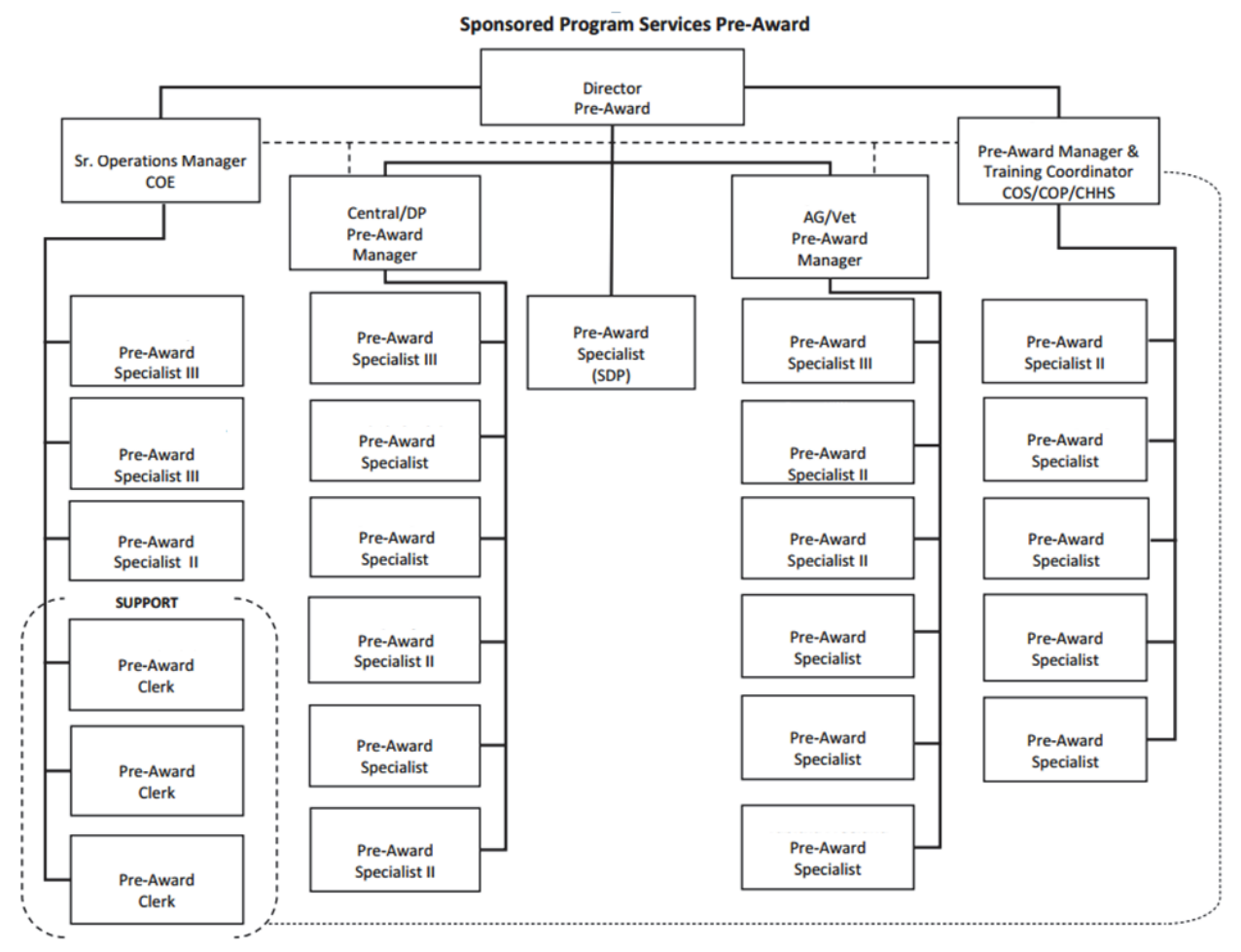

Figure 1. Hierarchy of Pre-Award SPS Office

\subsection{Problem Statement}

In the peak months of grant application, once the number of proposals is above 350, it will exceed the maximum capacity of the office. With the most urgent problem that SPS is facing at is lack of workforce in peak months, late submissions rate will also increase accordingly.

\subsection{Objective}

The objective of this Six Sigma project is dedicated to improve external customer satisfaction level by decreasing late proposal submission rate.

\subsection{DMAIC Process}

\subsubsection{Define}

In Define phase, a Six Sigma team was created, worked with director directly, and led by a black belt, who is a professor at Purdue and majored in Six Sigma and quality control. Project chart and project schedule were made. Voice of customer and voice of business were identified. The "Define" stage is influential in aligning the project with the voice of the customer and specific outputs. While the project sponsor communicated the key bottleneck in the system, the exact definition of the area for improvement and project goals needed to align with the strategic business plan of the institution, as well as the voice of the customer.

The methodology presented by Ray and Das provides three different avenues for project selection (Ray, 2010). The first looks at performance metrics from available data. Using performance metrics, the "big Y" strategic area is connected to direct process outputs "small 
y's", relating to a product, a specific defect and the process from which that defect occurs. This first process was the methodology utilized by the project team. To accomplish this goal, a SIPOC chart was created and is shown in Table 1 below.

\begin{tabular}{|c|c|c|c|c|}
\hline Suppliers & Inputs & $\begin{array}{l}\text { Process } \\
\text { Steps }\end{array}$ & Outputs & Customers \\
\hline $\begin{array}{l}\text { Academic } \\
\text { Departments/Discov } \\
\text { ery Park } \\
\text { Researchers/PI }\end{array}$ & 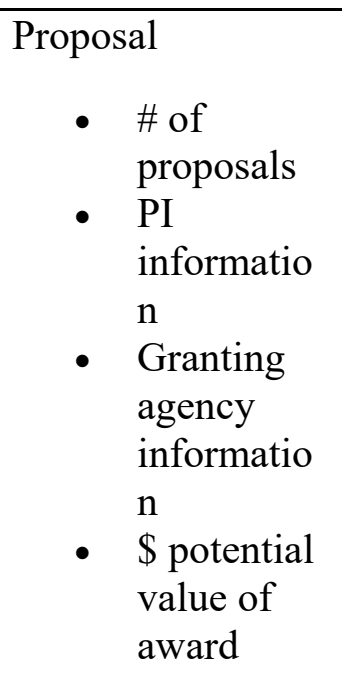 & $\begin{array}{l}\text { Review } \\
\text { proposal } \\
\text { for type }\end{array}$ & $\begin{array}{l}\text { Proposal } \\
\text { categorization } \\
\text { - } \\
\text { Skill } \\
\text { required } \\
\text { matrix } \\
\text { - } \\
\text { Proposal } \\
\text { categoriz } \\
\text { ation log }\end{array}$ & $\begin{array}{l}\text { SPS Staff member } \\
\text { Academic } \\
\text { Departments/Discov } \\
\text { ery Park } \\
\text { Researchers/ PI }\end{array}$ \\
\hline $\begin{array}{l}\text { Internal SPS } \\
\text { process }\end{array}$ & $\begin{array}{l}\text { Proposal } \\
\text { categorization } \\
\text { - } \\
\text { Skill } \\
\text { required } \\
\text { matrix } \\
\text { - } \\
\text { Proposal } \\
\text { categorizati } \\
\text { on log } \\
\text { - } \text { \# of } \\
\text { proposals } \\
\text { currently } \\
\text { assigned }\end{array}$ & $\begin{array}{l}\text { Assign } \\
\text { proposal }\end{array}$ & 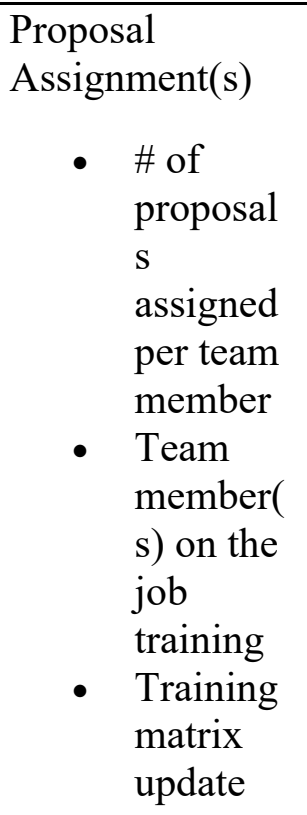 & SPS staff member \\
\hline $\begin{array}{l}\text { Granting agency } \\
\text { Academic } \\
\text { Departments/Discov }\end{array}$ & $\begin{array}{ll}\text { - } & \text { Granting } \\
\text { agency } \\
\text { regulations } \\
\text { - } & \text { Required } \\
\text { PI } \\
\text { documenta } \\
\text { tion }\end{array}$ & $\begin{array}{l}\text { Proposal } \\
\text { Submissi }\end{array}$ & $\begin{array}{l}\text { Completed } \\
\text { proposal } \\
\text { - Cycle } \\
\text { time per } \\
\text { proposal }\end{array}$ & $\begin{array}{l}\text { Academic } \\
\text { Departments/Discov } \\
\text { ery Park } \\
\text { Researchers/PI }\end{array}$ \\
\hline
\end{tabular}




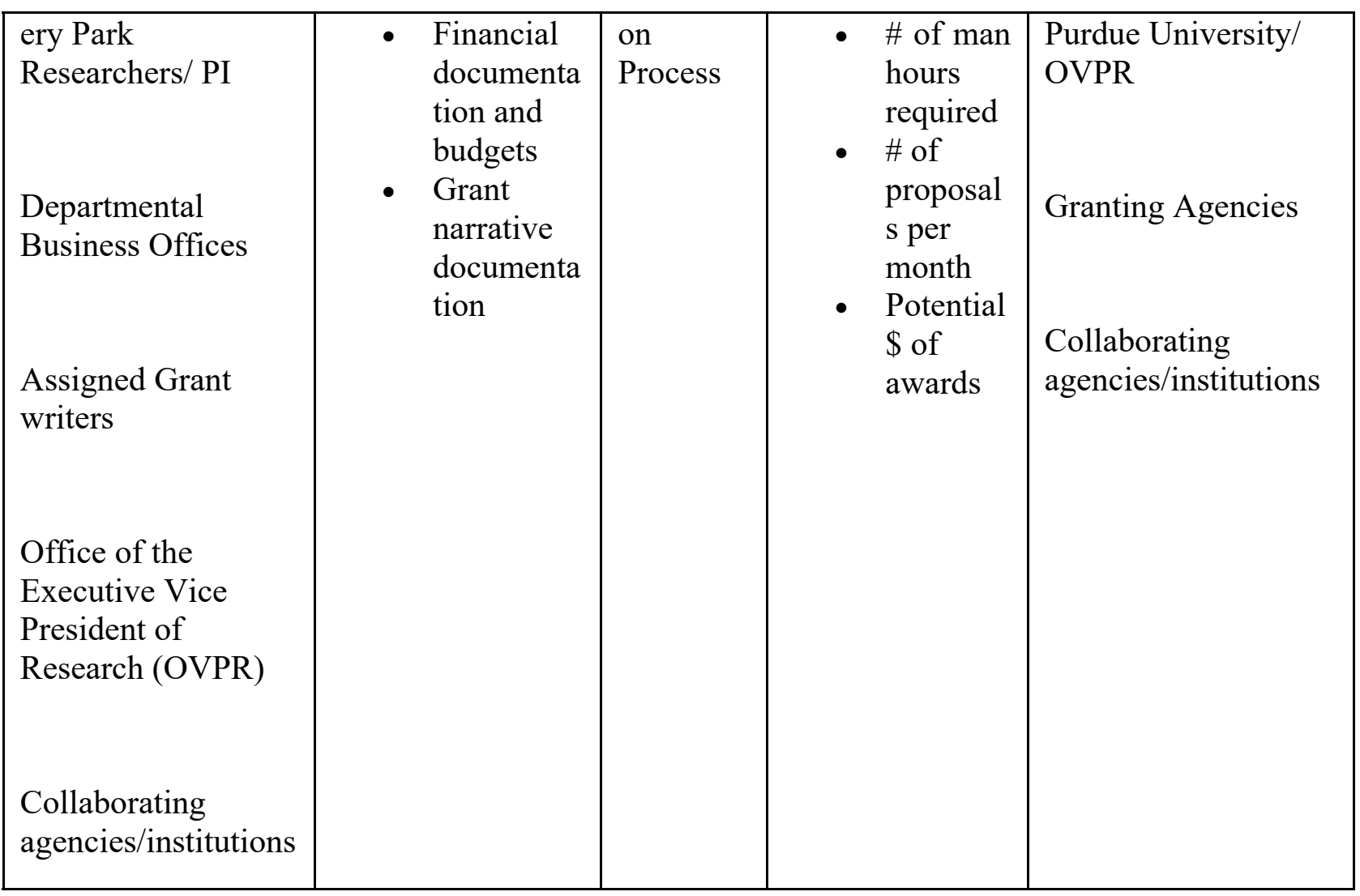

Table 1. SIPOC of Pre-Award Office

In this project, the project team focused on the proposal submission process in terms of the major objective illustrated previously. After identifying the stakeholders, the customers and goals associated with this project, process flow chart were created to understand the current state of proposal submission process (See Figure 2). 


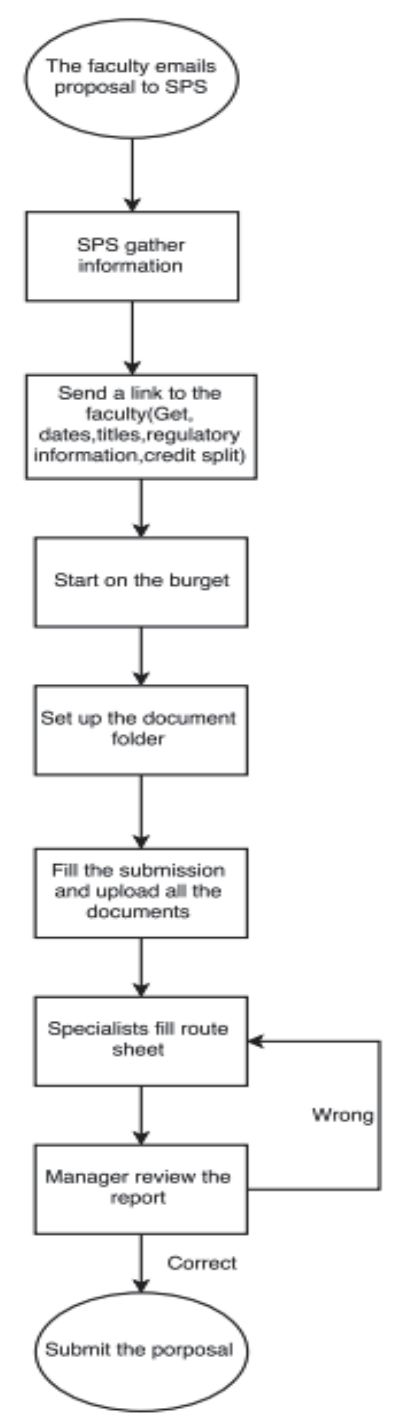

Figure 2. Process Flow Chart of Pre-Award Proposal Submission Process

Among all the months, February, June and September are peak months of Sponsored Program Activity and September has the largest amount of funding per year. College of Engineering PreAward Center (EPC) has the highest number of count (See Figures 3 and 4). 


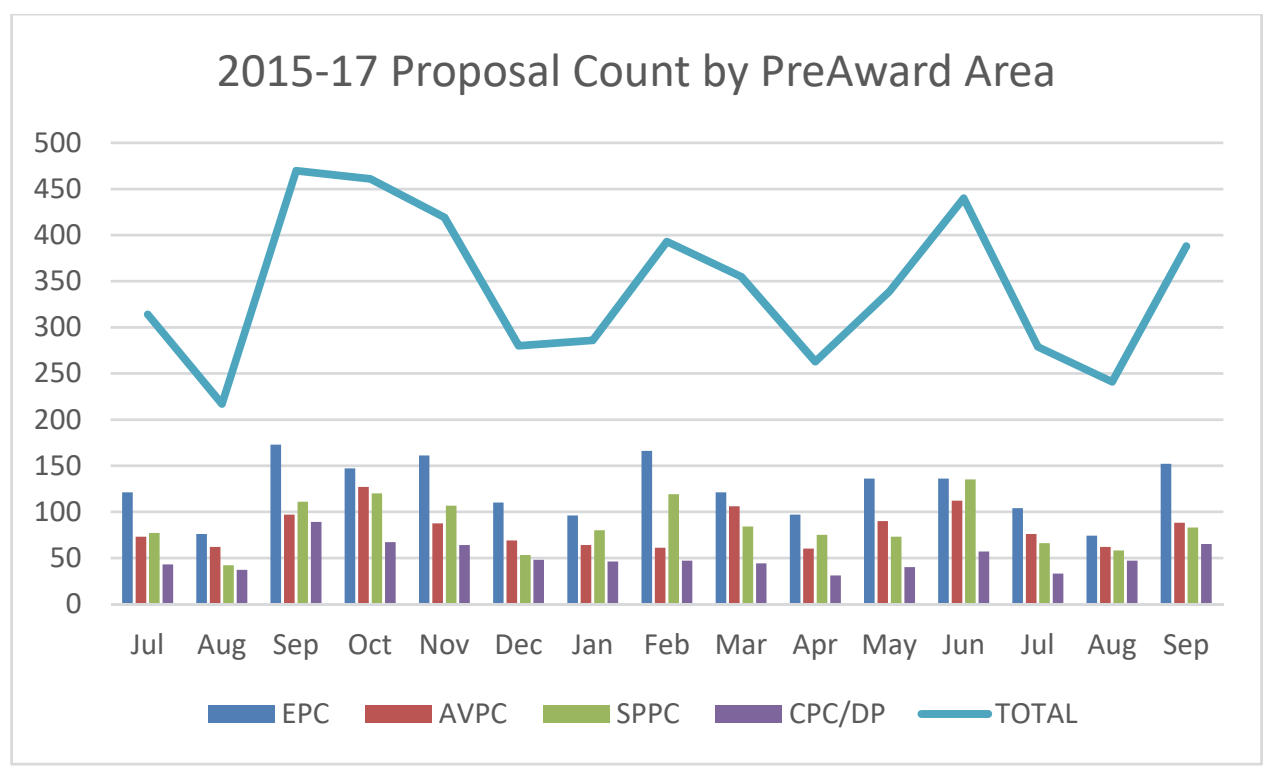

Figure 3. Number of Proposals in Pre-Award Area (2015-2017)

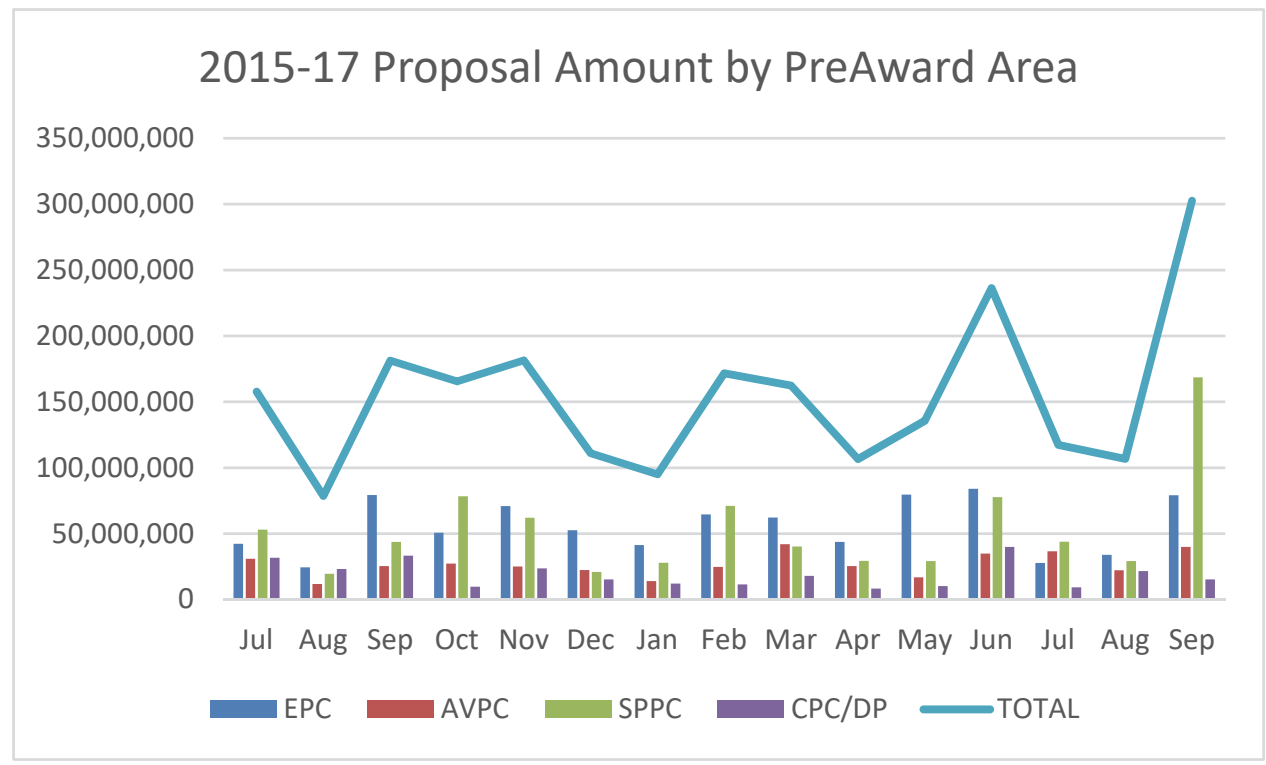

Figure 4. Amount of Proposals in Pre-Award Area (2015-2017)

The project team defined and calculated the defect rate, which is the rate of late proposal submission. During 2015 September to 2016 September, 3518 proposals were accepted and 20 proposals were late submission. The defective rate is $0.56 \%$. The defects per million opportunities (DPMO) are 5685.

Additionally, information from the customer service surveys were reviewed to identify the voice of the external customer, as defined by Purdue University who receives both funds and public recognition through sponsored programs office. According to the survey, the overall satisfactory of the process is surprisingly good, for all the responses to this question are 'very satisfied'. However, this may not imply the truth as people working with the office are usually generous about their comments. When we look into specific sections of the survey, the ratios of people 
'strongly agree' that they have received effective support 'at the beginning' and 'during' the process are only $61.33 \%$ and $70.67 \%$, respectively. In addition, there are over $23 \%$ of the people do not highly agree that the administrative support provided by the office could help them save some time. Consequently, the result indeed indicates the importance to improve our customer service to the next level.

\subsubsection{Measure}

In the Measure stage, the project team worked with the SPS office staff identified the key metrics and quantified the impacting factors related to variation within the proposal submission processes.

Business process mapping in swim lanes was developed to further understand the focus and help the Six Sigma team to identify where the wastes and non-value added activities were added in proposal submission process (See Figure 5). The minimum time need to complete a proposal submission is around 4.5 hours. However, the maximum hours needed in record is more than 80 hours. Huge variation of the process performance implies potential improvement opportunity in the process.

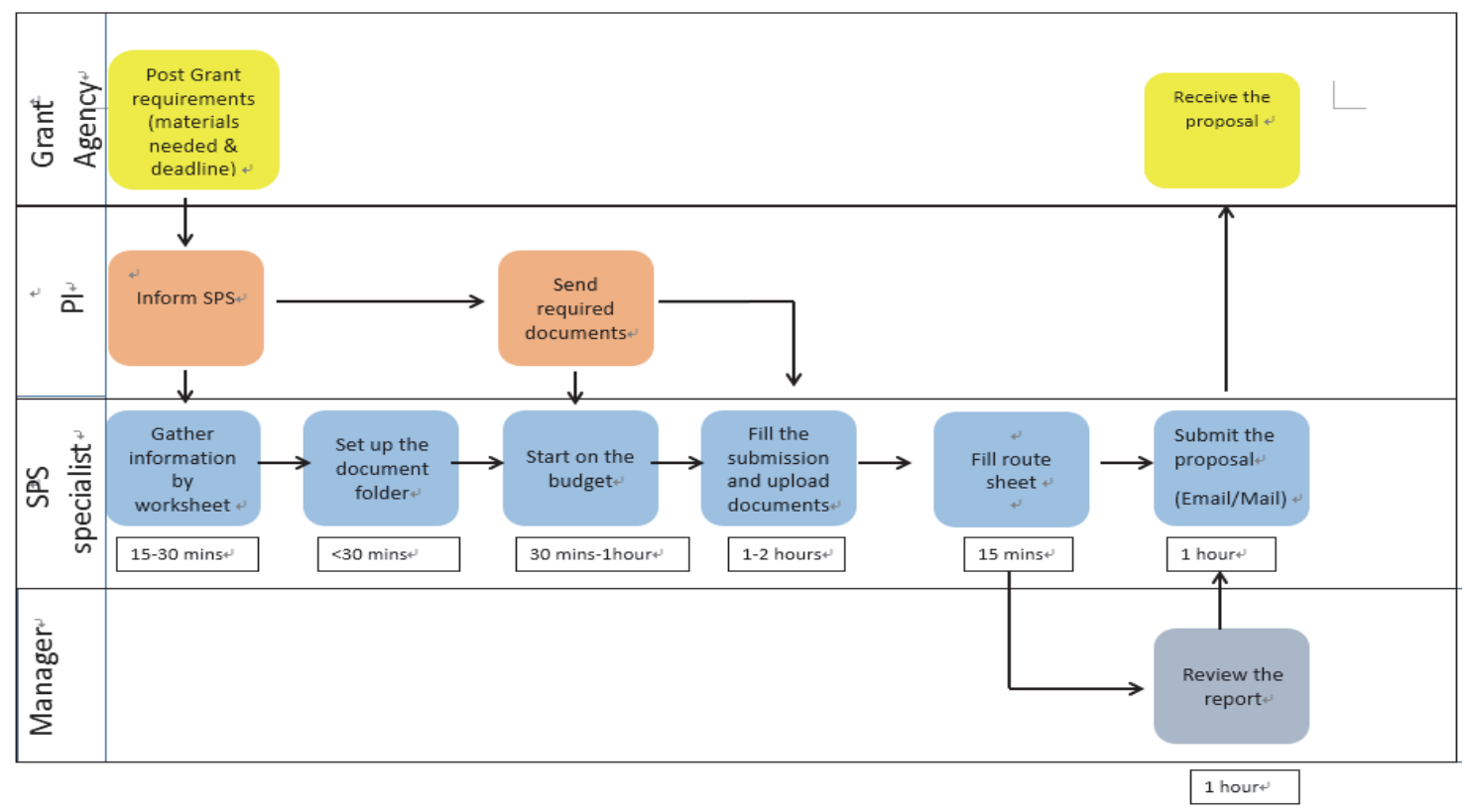

Figure 5. Process Mapping for Proposal Submission Process in Pre-Award Office

In proposal submission process, KPIVs are PI lead time and Proposal effort score. PI lead time is the time prior to the deadline the PI requested SPS's help and actively engaged with the specialist on the proposal development process. The SPS office tracks the lead time given by faculty to the SPS staff members, the factors associated with every grant proposal, such as financial documents and proposal narrative, and the time the last document is provided to the SPS staff prior to the submission deadline. Proposal effort score is calculated by a tool according to the complexity of each individual proposal. 


\subsubsection{Analysis}

After analyzing the data from September 2015 to September 2016, monthly defective rate is calculated (see Figure 6). Since the expected defect rate for SPS office is $0.5 \%$, the defect rates were higher than the expected rate in 5 months of a total of 13 months.

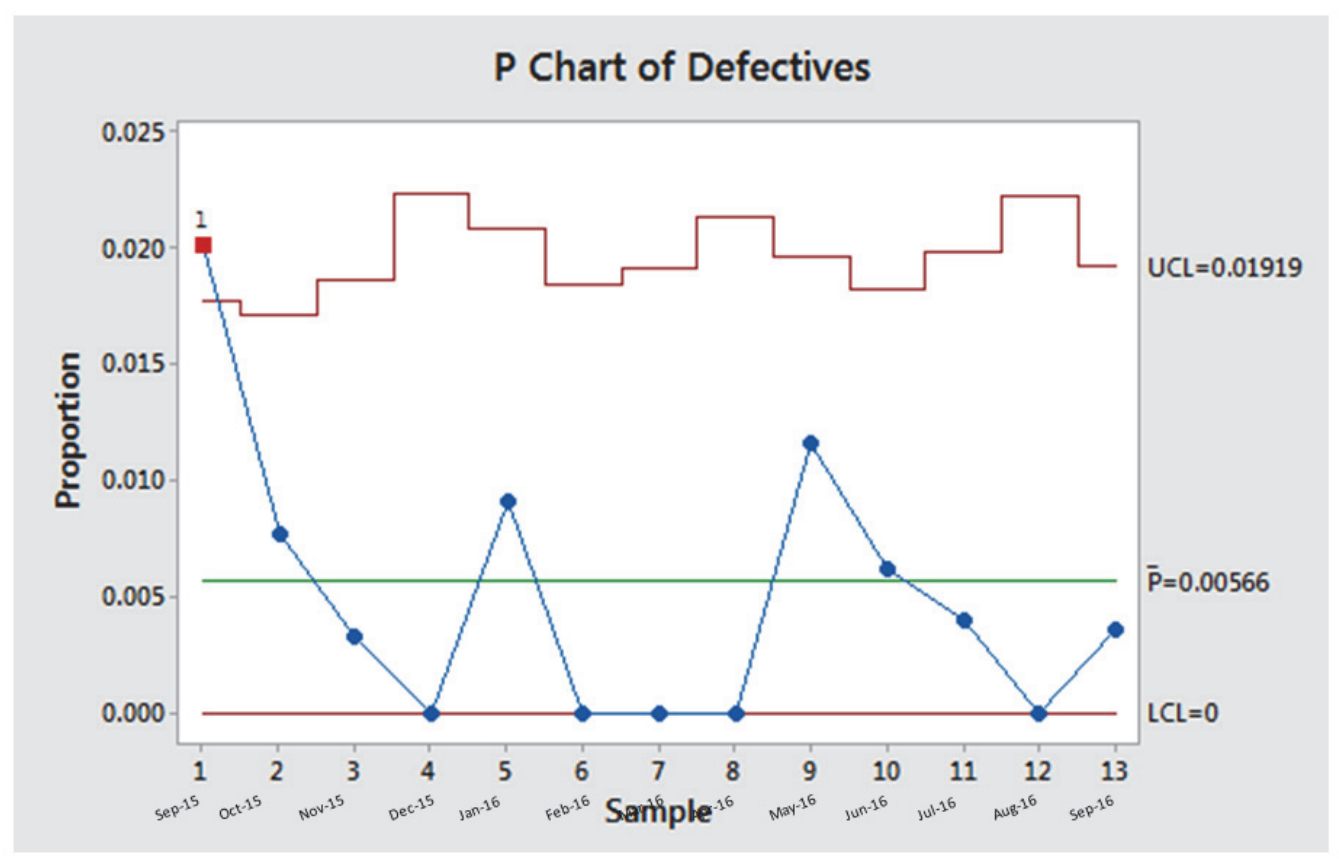

Figure 6. Defective Rate of Late Submission

The project team investigated correlations between individual faculty members, SPS staff members, grant sponsors and other factors recorded in the data logs of the SPS office. This data is compiled for every proposal. The project team looked to correlate the data obtained in the initial phases of the pre-award services to the final complexity score to better predict the number of hours required by the individual staff member for each proposal. These potential correlating factors were charted and graphed and can be found in Table 3 and Figure 7 below.

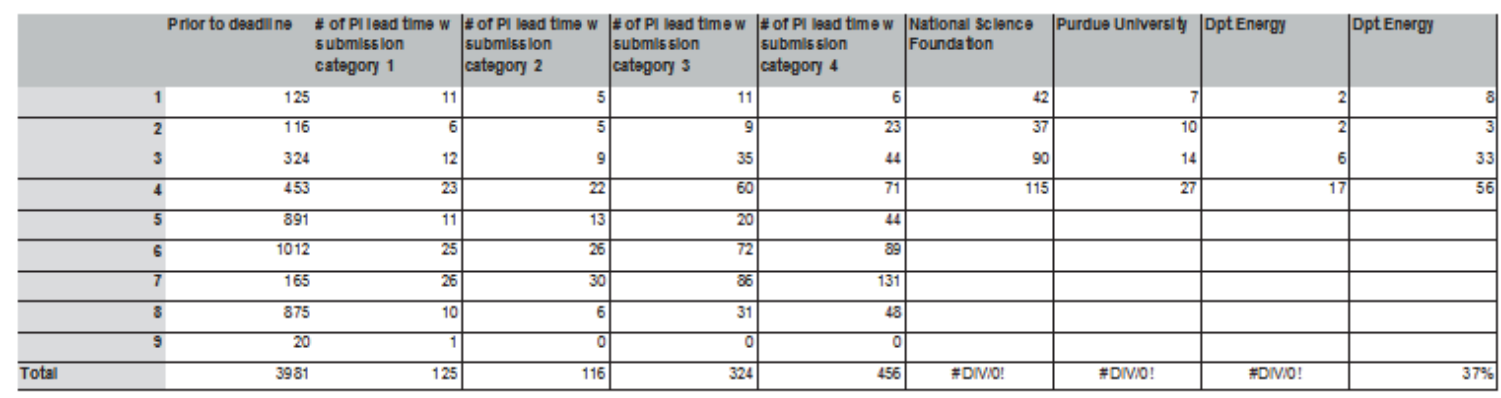

Table 3. Categories 1 to 4 of Proposal Submission Prior to Deadline on Terms of Different Grant Types 
The numbers in column "Prior to deadlines" are the categories of the submission time prior to the deadline. 1 to 9 corresponding to different levels as follow:

(1) Less than 30 minutes (2) 30-60 minutes (3) 1-2 hours (4) 3-4 hours (5) 4-8 hours

(6) More than 1 day (7) More than 1 week (8) Not applicable (9) After 5pm on due date

Category 9 is late submission. The expected submission time is at least 3-4 hours before the deadline because buffer time needed to be left for emergency issues.

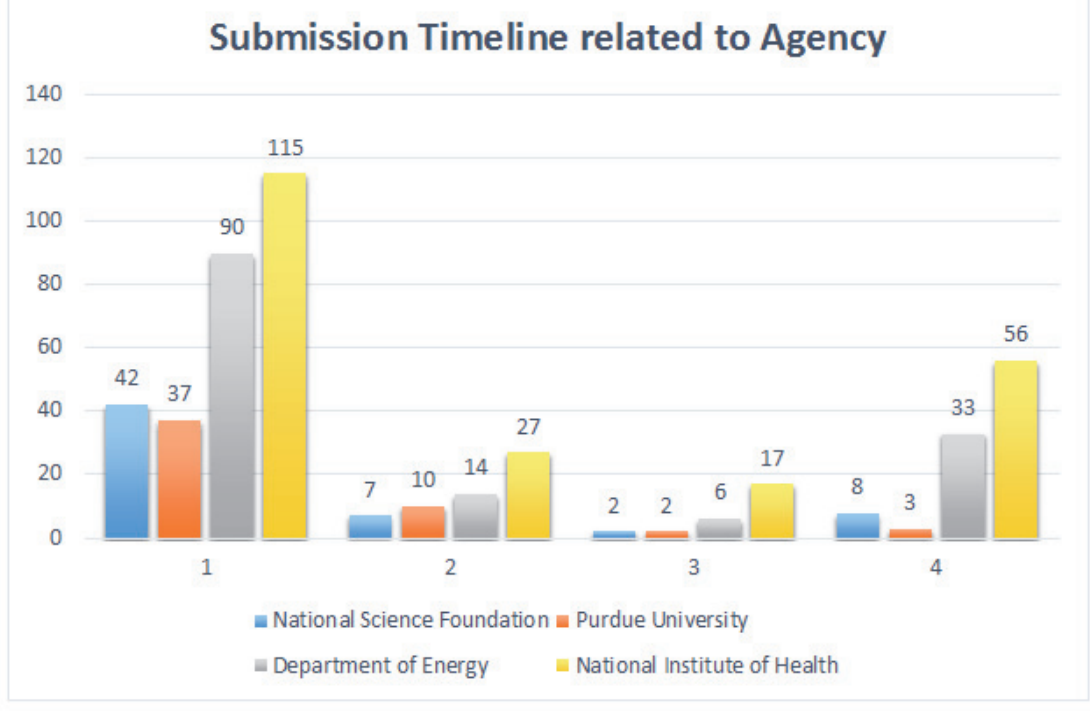

Figure 7. Categories 1 to 4 of Proposal Submission Prior to Deadline in Terms of Different Grant Types

Currently, $37 \%$ of proposals were submitted only 3 to 4 hours before the deadline (See Table 3 ). Even the employees have already been working overtime, the late submission or last-minute submission still happened.

The results show that the major reasons for last-minute submission to even late submission:

(1) One major reason for the last- minute submission is the external variable- short PI lead time. As PI lead time refers to the time that the PI provided to the SPS office before the submission deadline, this means the PI may fail to allow themselves and the SPS staff enough time for their project to be completed in a timely fashion.

Regression relationship test result shows that the complexity of the proposal and PI lead time is statistically related to final submission prior to grant deadline (See Table 2). The 'Proposal Effort Score' is a measurement of the complexity of each proposal, which is related to submission method, sponsor forms and some other internal properties. The SPS office has its own tool to calculate it. The value of the 'Proposal Effort Score' is dependent to each case and cannot be 
changed. As a result, in order to decrease the late submission rate, the focus should be put on PI lead time because the complexity of each individual proposal is fixed.

\begin{tabular}{|l|r|r|r|r|}
\hline Parameter & Estimate & Standard Error & $\mathrm{t}$ Value & $\mathrm{Pr}>|\mathrm{t}|$ \\
\hline Intercept & 4.143317456 & 0.08357348 & 49.58 & $<.0001$ \\
\hline Proposal_Effort_Scor & -0.018993017 & 0.00115132 & -16.50 & $<.0001$ \\
\hline PI_Leadtime & 0.281470772 & 0.01207366 & 23.31 & $<.0001$ \\
\hline
\end{tabular}

Table 4. Regression Analysis for Proposal Effort Score and PI Lead Time with Final Submission Prior to Grant Deadline

(2) Another major reason is related to the internal variable- unbalanced workload. This variable is very hard to quantify but was pointed out by the top management. Senior specialists work over time on high complexity scored proposal, while new specialists still have spare time because firstly, they are unable to deal with high complexity scored proposals, secondly the number of matched complexity scored proposals is limited.

Currently, there is no proposal assignment process. A fishbone diagram was created which looked at the factors associated with imbalanced workload for the SPS office staff. The fishbone includes the factor groupings of those factors associated with the Principle Investigator, the SPS Staff, the existing process and the associated granting agency. These factors were selected for the number of variables which can potentially impact the complexity and time required for the submittal of a proposal. As staff members work on numerous proposals simultaneously, with multiple granting agencies and various faculty members, each of these factors not only impact complexity but also potentially impact each other. The fishbone diagram can be found in Figure 8 . 


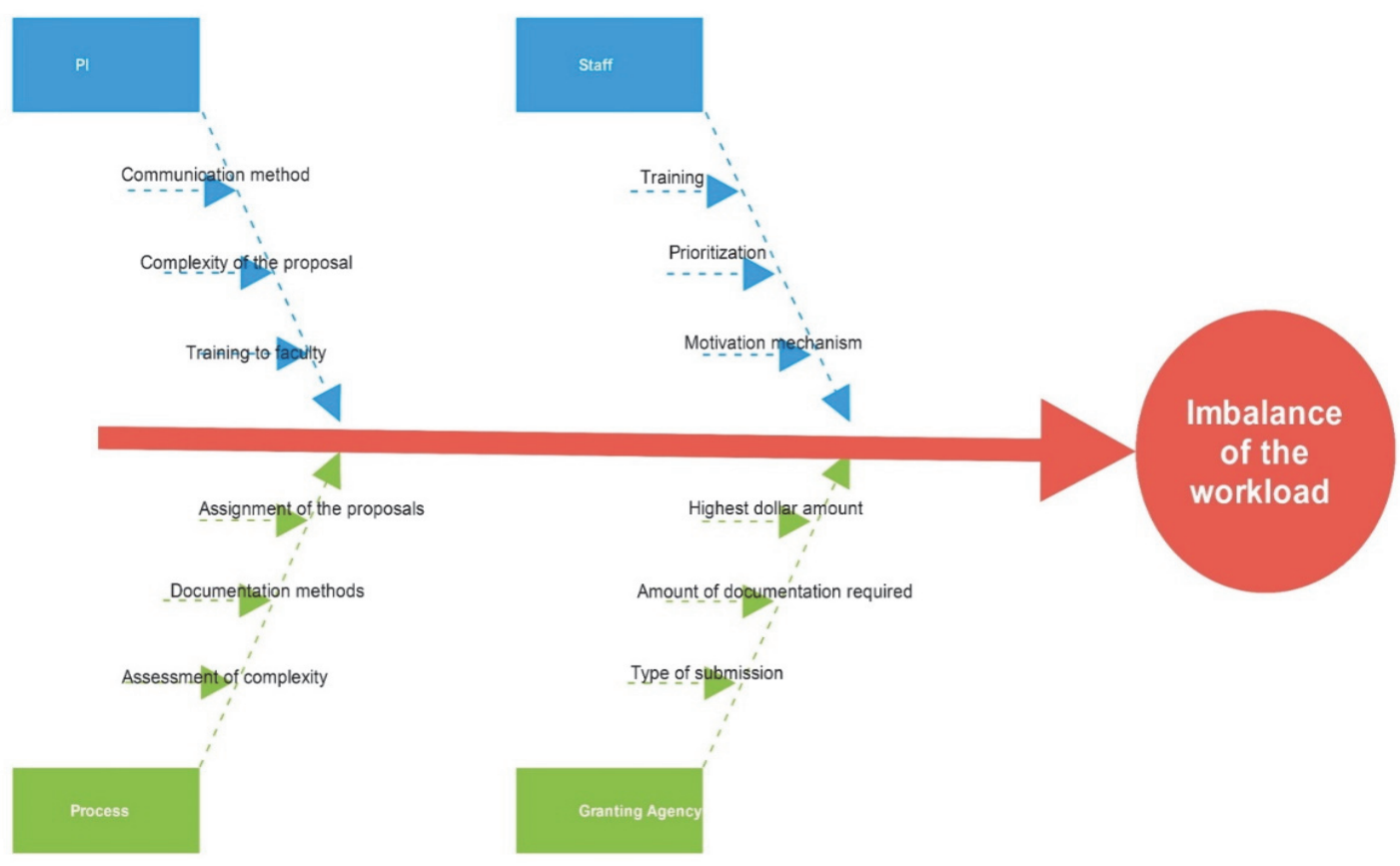

Figure 8. Fishbone Diagram for Imbalanced Workload

(3) The third reason is the internal wastes existed in the service process. Wastes identified in the proposal submission process in Pre-Award Office include as the following Table 5:

\begin{tabular}{|l|l|}
\hline Wastes & Description \\
\hline Transportation & $\begin{array}{l}\text { The emails of required materials for each proposal will } \\
\text { back and forth between PI and specialists several } \\
\text { times. } \\
\text { Different PI has different response to time emergency, } \\
\text { it brings the large variance and unpredictability for the } \\
\text { final submission time. }\end{array}$ \\
\hline Waiting time & $\begin{array}{l}\text { Waiting too long is the most common complaint from } \\
\text { the customers, but waiting for the PI to submit the } \\
\text { materials required most of the time. } \\
\text { Unbalanced flow of documents activities caused long } \\
\text { waiting time for both the PI and specialists. }\end{array}$ \\
\hline Defect & $\begin{array}{l}\text { The specialists need to rework on some projects for } \\
\text { two or even three times, because the proposal is not } \\
\text { fulfilled the requirements by the Granting agency. } \\
\text { "Defected" service will aggravate the workforce crisis. }\end{array}$ \\
\hline
\end{tabular}

Table 5. Wastes Identified in the SPS Office 


\subsubsection{Improve}

After analyzing the data, the project team hopes to firstly improve the imbalanced workload experienced by the SPS staff by making the "quick win" actions (actions that can be easily implemented without roadblocks or concerns):

1) Establish a mechanism for quantifying complexity of proposals at the beginning of the proposal process. Proper training should be provided to PI on how to self-evaluate the complexity of their documents. Then the complexity, as known as the effort score, may be transformed into quantitative time period. This will give the SPS officer more time and reduce hassles.

2) Establish a corresponding training matrix to assist the SPS office in cross training their employees to better distribute the proposals and thereby even the workflow.

Through these actions, the overall capacity of the SPS Pre-Award office would increase, as well as the level of quality for the review and potentially a decrease in the overall cycle time of the pre-award process.

FMEA is generated to perform the risk assessment (See Figure 9). The actions were already taken including the followings:

1) Automatic email reminder to PI according to the proposal submission status

2) Clearly diagram of the proposal timeline on SPS website.

3) Work distribution sheet was generated and workload data will be monitored monthly.

4) The structure of current specialists was modified and a few level-two specialists were promoted to senior level.

\begin{tabular}{|c|c|c|c|c|c|c|c|c|c|c|}
\hline $\begin{array}{l}\text { Process } \\
\text { Step/Input }\end{array}$ & $\begin{array}{l}\text { Potential Failure } \\
\text { Mode }\end{array}$ & $\begin{array}{l}\text { Potential } \\
\text { Failure Effects }\end{array}$ & & Potential Causes & & $\begin{array}{l}\text { Current } \\
\text { Controls }\end{array}$ & & & $\begin{array}{l}\text { Actions } \\
\text { Recommended }\end{array}$ & $\begin{array}{l}\text { Actions } \\
\text { Taken }\end{array}$ \\
\hline $\begin{array}{l}\text { What is the } \\
\text { process step } \\
\text { and input } \\
\text { under } \\
\text { investigation? }\end{array}$ & $\begin{array}{l}\text { In what ways does } \\
\text { key input go } \\
\text { wrong? }\end{array}$ & $\begin{array}{l}\text { What is the } \\
\text { impact on the } \\
\text { Key Output } \\
\text { Variables } \\
\text { (Customer } \\
\text { Requirements)? }\end{array}$ & $\begin{array}{l}\text { Severity } \\
\text { (1-5) }\end{array}$ & $\begin{array}{l}\text { What causes the Key } \\
\text { Input go wrong? }\end{array}$ & $\begin{array}{l}\text { Occurrence } \\
\text { (1-5) }\end{array}$ & $\begin{array}{l}\text { What are the } \\
\text { existing } \\
\text { controls and } \\
\text { Procedures that } \\
\text { prevent the } \\
\text { cause of Failure } \\
\text { Mode? }\end{array}$ & $\begin{array}{l}\text { Detection } \\
\text { (1-5) }\end{array}$ & $\begin{array}{l}\text { RPN= } \\
S^{*} O^{*} D\end{array}$ & $\begin{array}{l}\text { What are the } \\
\text { actions for } \\
\text { reducing the } \\
\text { occurrence of } \\
\text { the cause or } \\
\text { improving } \\
\text { detection? }\end{array}$ & $\begin{array}{l}\text { What are } \\
\text { the } \\
\text { completed } \\
\text { actions } \\
\text { taken } \\
\text { with the } \\
\text { calculated } \\
\text { RPN }\end{array}$ \\
\hline $\begin{array}{l}\text { Gather } \\
\text { Information } \\
\text { by worksheet }\end{array}$ & $\begin{array}{l}\text { Didn't get } \\
\text { information by } 3 \\
\text { weeks before the } \\
\text { deadline }\end{array}$ & $\begin{array}{l}\text { It will effect the } \\
\text { following } \\
\text { application } \\
\text { process }\end{array}$ & 2 & $\begin{array}{l}\text { PI didn't answer the } \\
\text { questions correctly } \\
\text { and on time }\end{array}$ & 5 & $\begin{array}{l}\text { Tools online for } \\
\text { them to figure } \\
\text { out the deadline } \\
\text { online }\end{array}$ & 1 & 10 & $\begin{array}{l}\text { Email reminder } \\
\text { and tell them } \\
\text { you are late } \\
\text { already }\end{array}$ & \\
\hline $\begin{array}{l}\text { Finalize the } \\
\text { budget }\end{array}$ & $\begin{array}{l}\text { Errors of the } \\
\text { budget. } \\
\text { Missing } \\
\text { information }\end{array}$ & $\begin{array}{l}\text { Impact finalize } \\
\text { the proposed } \\
\text { submission }\end{array}$ & 3 & $\begin{array}{l}\text { Pl are late. SPS didn't } \\
\text { have the information }\end{array}$ & 4 & $\begin{array}{l}\text { Written } \\
\text { deadline online. } \\
\text { Staff reminder }\end{array}$ & 2 & 24 & & \\
\hline $\begin{array}{l}\text { Fill the } \\
\text { submission \& } \\
\text { upload } \\
\text { documents }\end{array}$ & $\begin{array}{l}\text { Grant agency } \\
\text { didn't receive the } \\
\text { submission. } \\
\text { Submission needs } \\
\text { revision and } \\
\text { correction }\end{array}$ & $\begin{array}{l}\text { The later the } \\
\text { harder to check } \\
\text { the submission } \\
\text { package }\end{array}$ & 4 & $\begin{array}{l}\text { External: } \\
\text { System, PI is late or } \\
\text { didn't prepare the } \\
\text { documents needed. } \\
\text { Internal: Unbalanced } \\
\text { workload; } \\
\text { Staff's } \\
\text { confidence/experience } \\
\text { to complete the work }\end{array}$ & 5 & $\begin{array}{l}\text { Written } \\
\text { deadline online; } \\
\text { checklist of the } \\
\text { budget, tell } \\
\text { them what } \\
\text { documents we } \\
\text { have and we } \\
\text { need }\end{array}$ & 3 & 60 & $\begin{array}{l}\text { Updated } \\
\text { instructions } \\
\text { online; } \\
\text { Workload } \\
\text { distribution } \\
\text { sheet (Look at } \\
\text { the frequent } \\
\text { customers and } \\
\text { assign the } \\
\text { customers to } \\
\text { staff } \\
\text { appropriately; } \\
\text { monitor the } \\
\text { monthly } \\
\text { workload } \\
\text { data) }\end{array}$ & \\
\hline
\end{tabular}

Figure 9. Failure Mode of Effect Analysis (FMEA) 


\subsubsection{Control}

The project team will assist the SPS office to documented all the improved actions and generate standard proposal assignment process. Sine this department is belonged to Purdue University, it is hard to calculate the financial benefits. Workload data will be monitored and reviewed monthly by director in order to adjust the workload on time.

Currently, this project completed the first three phases and is still working on the Improve and Control phase. The project team will still work for both implementation and ongoing sustainability through the Improve and Control phases of the DMAIC framework. This project has created numerous challenges in working with mostly intangible factors that are both hard to quantify and rarely tracked by the organization. Additionally, the stakeholders have differing opinions on the definition of "value added" activities and key success factors. As a project team, team management and communication with the project sponsor have been challenging at times. Each of these issues has created a true to life scenario for executing a Six Sigma project. The major benefit of implementation Six Sigma in both manufacturing and service is considerable improvement in the bottom line. This is also the ultimate drive for Six Sigma. However, in this case study, SPS is a service department at Purdue and very hard to track the gained financial benefits. This is also the specialty of implementation of Lean Six Sigma in education area.

Benefits of the implementation of Six Sigma in this case includes:

1. Improved customer satisfaction

2. Increased employee morale

3. Gained admit from top management for Six Sigma

4. Dissemination of problem solving methodologies and tools in Six Sigma.

\section{Discussion - Challenges and Lessons Learned}

Type of industry and nature of the service will decide the complexity of Six Sigma project in service sectors. Nakhai \& Neves (2009) introduced that there are two major types of services, which are process-based, such as banking, telecommunications and knowledge-based, such as legal service and health industry. Service provided in SPS is obvious belonged to knowledgebased. Customers various expectations, communication method and even their personality play a critical role in the success of grant proposal. High human behavior component increases the unpredictability of the whole service delivery process and then highly increases the complexity to identify the root cause for Six Sigma team. In order to resolve this problem, Six Sigma team needs to challenge initial assumption and seek input from as many sources as possible and shouldn't have preconceived notions for causes, they need to use analytics tools and let data to reveal the true problems and root cause. Biolos (2002, pp. 3-5) and Antony (2006, pp. 239-241) also suggested that search relentless for root causes. In the beginning, the considered input variables were only from one source, which is the sponsored program service (SPS) at Purdue. However, there are many sources that will also attribute to the imbalanced workload in SPS. For example, the principle investigators' communication method will affect workload distribution because if their personality is to upload the required documents in the last minute of the deadline, the workload will increase dramatically before the grant deadline. Besides, the granting agency will also affect the output variable because different types of submission will decide the complexity of the project, leading to different amount time spent by the employees. 
Commitment from top management is always the critical success factor for application, however over control from top management will jeopardize or impede the implementation procedures. In this project, the department director directly pointed out the problem that need to resolve and gave the potential solutions in the very beginning. Top management jumped to solutions and conclusions directly instead of following the DMAIC or problem solving process. The function of Six Sigma team is to prove which solution is correct instead of analyzing the problem, find the "real" root cause and get the optimal solution. Even Six Sigma team has the pressure for quick solutions, the project team should be aware of jumping to conclusions and ignore the easy opportunities. Instead of staring on few variables and the project team should look at the big picture at first before diving into analysis right away and ignore the other possible input variables.

The Six Sigma initiative must be focused on the customer. In Institutions of Higher Education, it is hard to define the "real" customer. The external customers for this SPS department are staff or principle investigators at Purdue. However, their satisfaction level will not affect the bottom line. That' why the director is insisted to focus on the internal customers, who are the employees in SPS, to take balancing the workload as the objective of this Six Sigma project, in order to improve employee moral instead of improving on-time proposal submission rate.

\section{Conclusions}

In this case study, the project team utilized the DMAIC process to improve a service process in higher education. The initial of this Six Sigma project is not financially benefits but the desire to improve the current workload distribution by the top management. The obstacles met includes high human being component involved, over control from top management, hard to measure the variables and find real root causes, and pressure for quick conclusions etc. Six Sigma tools like process analysis, evaluation and decision making, and cause analysis, ideas creation tools and basic quality tools are used. The implementation process demonstrates the power of Six Sigma in service process in Higher education. However, even if Six Sigma can be extended to many operations, but new concepts and tools in modified areas should still need to be developed, especially in processes with high human being component and various customer expectations.

\section{References}

Antony, J. (2006). Six Sigma for service processes. Business Process Management Journal, 12(2), 234-248.

Biolos, J. (2002). Six Sigma meets the service economy—Six Sigma: it's not just for manufacturing. Harv Manag Updat, 7, 3-5.

Furterer, S., \& Elshennawy, A. K. (2005). Implementation of TQM and lean Six Sigma tools in local government: a framework and a case study. Total Quality Management \& Business Excellence, 16(10), 1179-1191.

George, M. L., \& George, M. (2003). Lean Six Sigma for service (p. 273). New York, NY: McGraw-Hill.

Goh, T. N. (2002). A strategic assessment of Six Sigma. Quality and Reliability Engineering International, 18(5), 403-410. 
Hensley, R. L., \& Dobie, K. (2005). Assessing readiness for six sigma in a service setting. Managing Service Quality: An International Journal, 15(1), 82-101.

Kumar, M., Antony, J., Madu, C. N., Montgomery, D. C., \& Park, S. H. (2008). Common myths of Six Sigma demystified. International Journal of Quality \& Reliability Management, 25(8), 878-895.

Nakhai, B., \& Neves, J. S. (2009). The challenges of Six Sigma in improving service quality. International Journal of Quality \& Reliability Management, 26(7), 663-684.

Pyzdek, T., \& Keller, P. A. (2014). The Six Sigma handbook (p. 25). McGraw-Hill Education.

Ray, S., Das, P. (2010), "Six Sigma project selection methodology”, International Journal of Lean Six Sigma, 1, 4, 293-309.

Tjahjono, B., Ball, P., Vitanov, V. I., Scorzafave, C., Nogueira, J., \& Srivastava, S. (2010). Six Sigma: a literature review. International Journal of Lean Six Sigma, Vol.1, No.3, pp.216-233. 